\title{
MANAGEMENT OF NATURAL HISTORY COLLECTION OF GYMNASIUM KARLOVAC: PREPARATION FOR THE EXHIBITION IN 2016 AND PLANS FOR THE FUTURE
}

\author{
Luka ČoraK ${ }^{1} \&$ Antun Milinković ${ }^{2}$ \\ ${ }^{1}$ Karlovac City Museum, Strossmayerov trg 7, 47000 Karlovac, Croatia \\ ${ }^{2}$ Gymnasium Karlovac, Rakovac 4, 47000 Karlovac, Croatia
}

Čorak, L. \& Milinković, A.: Management of Natural History Collection of Gymnasium Karlovac: preparation for the exhibition in 2016 and plans for the future. Nat. Croat., Vol. 27, No. 1., 243-255, 2018, Zagreb.

The Natural History Collection of Karlovac Gymnasium is one of the oldest and most important school collections in Croatia and is protected as a part of our cultural heritage. For the 250th school anniversary it has been decided to present its contents to the public. Before the exhibition the collection was prepared and restored. This included: determining the initial state of the collection, inventory of the collection, changing the outdated species nomenclature in accordance with modern systematics, determining its value, digitization and restoration. The results showed that there were 1153 items in the collection, 635 (55\%) of which were damaged. For 613 (53\%) items the data were known. Only biological items were categorized according to their cultural heritage value and $100(17 \%)$ of them have an expert, $336(56 \%)$ an educational and $161(27 \%)$ a historical category. The conclusion is that the collection has been neglected and demands extensive restoration and a suitable storage environment in order to reach its full potential.

Key words: Karlovac City Museum, natural history collection, school collection, Karlovac Gymnasium, cultural heritage, restoration

Čorak, L. \& Milinković, A.: Upravljanje Prirodoslovnom zbirkom Gimnazije Karlovac: pripreme za izložbu 2016. i planovi za budućnost. Nat. Croat., Vol. 27, No. 1., 243-255, 2018, Zagreb.

Prirodoslovna zbirka Gimnazije Karlovac jedna je od najstarijih i najznačajnijih školskih zbirki u Hrvatskoj te je zaštićena kao kulturno dobro. Za 250. godišnjicu škole odlučeno je prezentirati njen sadržaj javnosti. Prije izložbe zbirka je pripremljena i obrađena. To je uključivalo: pregled stanja očuvanosti, inventarizaciju, usklađivanje zastarjelih naziva s modernom sistematikom, vrijednosnu kategorizaciju, digitalizaciju i restauraciju. Rezultati su pokazali da zbirka ima 1153 predmeta, od toga oštećenih 635 (55\%). Samo za 613 (53\%) predmeta su poznati podatci i autor. Vrijednosno su kategorizirani isključivo biološki predmeti od kojih 100 (17\%) ima stručnu, $336(56 \%)$ obrazovnu i $161(27 \%)$ povijesnu kategoriju. Zaključak je da se zbirka nalazi u zapuštenom stanju i zahtijeva opsežnu restauraciju i adekvatan smještaj kako bi se ostvario njezin puni potencijal.

Ključne riječi: Gradski muzej Karlovac, prirodoslovna zbirka, školska zbirka, Gimnazija Karlovac, restauracija 


\section{INTRODUCTION}

\section{The history of Karlovac Gymnasium and the origin of the Natural History Collection}

The rapid development of science, technology and industry in the $19^{\text {th }}$ century had an impact on all human activities, including education, which was required to make significant changes in all its segments. This period, in addition to higher and lower grammar schools (gymnasiums), saw the emergence of Realschule (vocational schools) throughout the Austrian Empire. They were increasingly more necessary and focused on students acquiring knowledge in technology, industry, construction, agriculture, forestry and other industries.

At that time, the well-known Royal Grammar School, founded in 1766 by the decree of Empress Maria Theresa, existed in the city. The Grammar School was managed by the Piarists ("Fratres piarum scolarum") until 1783. Following their departure, it was taken over by the Franciscans who built the second floor to the monastery to give the school the necessary facilities. The school also housed a specialized classroom for natural sciences. The collection boasted numerous herbarium specimens of plants and algae, a small number of zoological specimens, samples of minerals and teaching charts. After the reform in 1850, the Grammar School became the Lower Royal Grammar School. One of the reasons was the political and geographical division of Karlovac and its surroundings. In order to stimulate the economic development of the Military Border, a Lower Realschule was founded in Rakovac in 1851 and in 1863 it became the Imperial and Royal Realschule in Rakovac. Over the course of the next decades the special classrooms for natural sciences were being thoroughly equipped. Equipping the classrooms with the newest teaching aids, like the instruments, teaching charts, models and collections, reached a peak during the 1870s (Milinković, 2011).

In 1878 the Royal Grammar School in Karlovac became the High Royal Grammar School and, on the $1^{\text {st }}$ of August 1882, due to the increase in the number of students and the need for more space, Emperor Franz Joseph I signed the decree which merged the Realschule in Rakovac and the Royal Grammar School into one educational institution bearing the name High Royal Grammar Realschule in Rakovac (Fig. 1). This

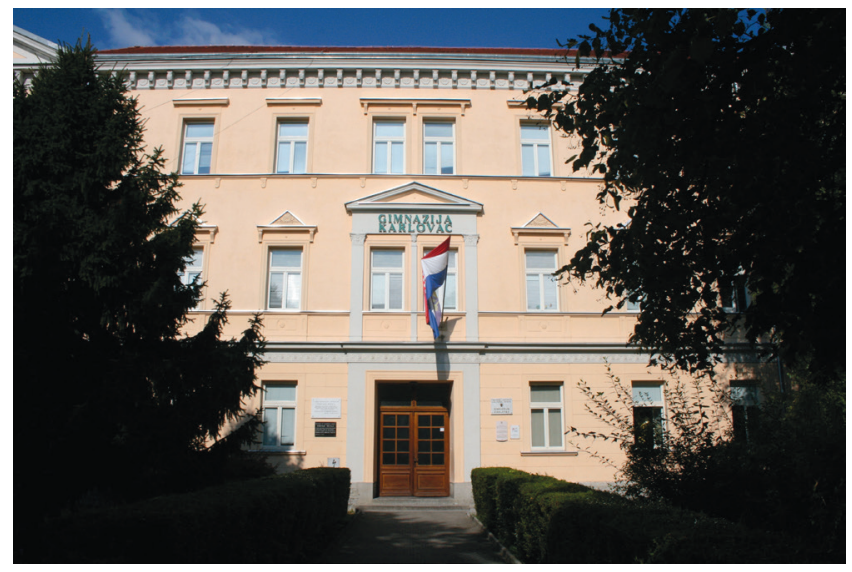

Fig. 1. Karlovac Gymnasium (photo: S. Adilović) 
unification resulted in a larger number of items in the natural history collection of the newly established school. After 1918 the collection was enlarged following a donation from the former Imperial and Royal Cadet School, which operated from 1872 to 1918 in Turanj, later in the town of Karlovac, and which also had a natural history collection (MiLInković, 2011).

After examining the school reports and books dealing with the history of the Grammar School (Gymnasium), Realschule and Cadet School, the historical and educational values of the exhibits, which mostly date from 1865 to 1880, were determined. Particularly noteworthy is the large number of preserved animals made in the taxidermy workshop

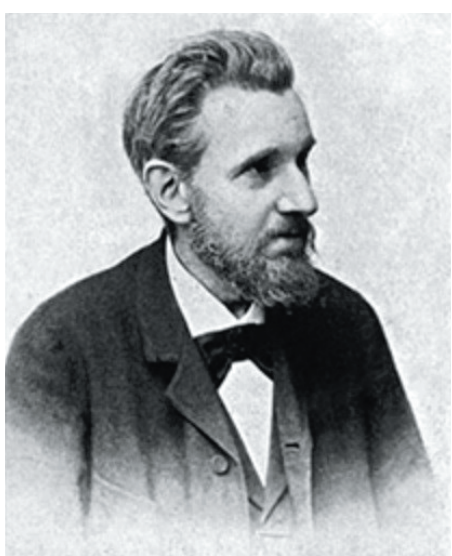

Fig. 2. Václav (Wenzel) Frič (after: ReIling \& Spunarova, 2005) of Vàcslav Frič (Fig. 2) and the taxidermy workshop of V. Hruby in Prague, the company Lenoir \& Forster and A. Pichlers $W^{\text {we }}$ \& Sohn in Vienna. Numerous teaching lithographs and charts came from the most prominent publishers. The publishers achieved exceptional quality by working with excellent printing houses. Optical aids were purchased from the following companies: C. Reichert in Vienna, W. Klein Wetzlar in Berlin and Carl Zeiss in Jena.

In the $20^{\text {th }}$ century new items were rarely added to the existing collection. To equip their special classrooms, schools mostly bought modern teaching aids with the selected topics of different areas of biology, human anatomy and physiology.

\section{Current state of the collection}

Long-term use, the date of production, changing the location and other factors present in the special classrooms left their mark on the collection. Therefore, after 2010, when some classrooms were converted into special classrooms for natural sciences, a list of the collection's inventory was made in order to determine the exact number of exhibits, the date of origin, the manufacturer, the collector or taxidermist and basic descriptions, to determine the value of the items, to update the terminology in accordance with modern systematics and to determine the state of preservation of the collection. The data obtained became the basis for further restoration activities, protection and conservation as well as for the finding of a suitable storage place. This formed the basis for creating a permanent exhibition where some of the objects could still be used for educational purposes according to the rules of museological methodology, and the rest of the collection would be deposited for occasional exhibitions, research or other activities.

Most of the items have an important methodological, pedagogical, professional, aesthetic and cultural value and therefore they were listed in the Register of Cultural Monuments of Croatia - List of Protected Cultural Monuments (Official Gazette, 2011). The Decision on the status of the collection was issued on 20 February 2015 by the Board for the Protection of Cultural Heritage of the Croatian Ministry of Culture in Zagreb (AnONYMous, 2016). 


\section{MATERIALS AND METHODS}

\section{Analysis of the collection}

The work on the natural history collection of Karlovac Gymnasium started in early 2014 and it was initiated by the Museum of Karlovac and Karlovac Gymnasium. The goals were the following: i) to present the collection at a special exhibition during the celebration of the school's $250^{\text {th }}$ anniversary, ii) to prevent further deterioration of the collection, iii) to protect the most delicate items of the collection and iv) to enlarge the holdings of the Karlovac Town Museum.

Expert analysis began in January 2014. The collection was divided into several smaller sub-collections to simplify and streamline the work. This division was done based on the similarity of the items, belonging to basic science, and the number of items in the collection. This resulted in the creation of the following sub-collections: algological, anthropological, botanical, geographical and economic, geological and mineralogical, malacological, mycological, microbiological, zoological as well as the equipment sub-collection. There were 10 sub-collections, containing in all 1153 items.

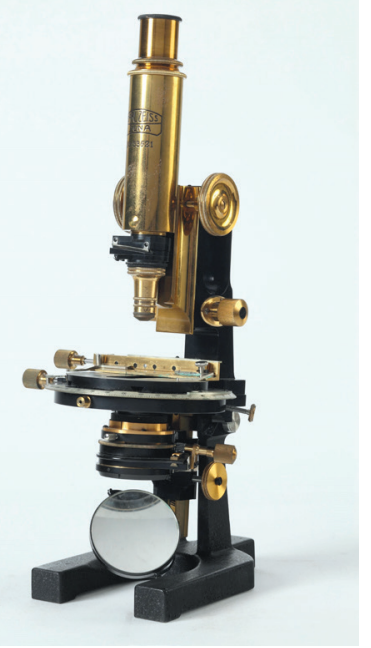

Fig. 3. Microscope: manufacturer C. Reichert, Vienna (photo: G. Vranić)

\section{Collection state assessment and processing}

All of the sub-collections were analyzed (Fig. 3). The analysis also included replacing outdated with modern terminology, for which the following databases were used: AlgaeBase (Guiry \& Guiry, 2015), Flora Croatica Database (FCD) (NiкоLıć (ed.), 2015) and United States Department Of Agriculture (USDA) Agricultural Research Service (ARS) - Fungal Databases (FAAR \& Rossman, 2015). While managing and analyzing the mycological collection, collaboration with experts was necessary. The two largest sub-collections, malacological and zoological were analyzed separately, which included replacing the outdated terminology with available modern biological nomenclature (taken from INTERNATIONAL CODE OF ZoOLOGiCAl Nomenclature, 2015). In order to complete the analysis it was necessary to collaborate with relevant institutions, which offered professional help.

For the purpose of preliminary determination and updating the terminology of the malacological and remaining zoological taxa sub-collection these databases were used: World register of marine species (WoRMS) (WoRMS Ed. BoArd, 2015), FishBase (Froese \& Pauly, 2015), Mammal species of the world (WILsON \& REEDER (eds), 2005), Avibase - the world bird database (LePAGE, 2015). A problem was encountered due to the almost illegible original names, outdated taxonomy and the absence of a catalogue of the collection.

Expert cooperation was requested from the Croatian Natural History Museum for the purpose of determination of the malacological collection and from Dr Henri Reiling in order to determine the original names of the models of Foraminifera and to find information about the taxidermist Václav (Wenzel) Frič (Reiling \& Spunarova, 2005). 
We created a standardized table for collection cataloging in which collected data were merged into a single list that would serve as a starting point for handling the collection in the future. The table had the following categories, according to the instructions from the Karlovac Conservation Department:

- Inventory number

- Name of the teaching aid

- Dimensions

- Time of manufacture

- Place of manufacture

- Manufacturer

- Call number

- Location

- Description

- State

While the collection was being catalogued, it was observed that a large number of items came from a small number of taxidermists and publishers: Václav (Wenzel) Frič, Lenoir \& Forster, A. PichlersWwe \& Sohn and Carl Gerold's Sohn. Therefore, a part of the research focused on studying the data about the aforementioned companies and taxidermists, especially Václav (Wenzel) Frič. According to these data it can be assumed that many other items without nomenclature or numbers were made in V. Frič's workshop (ReILING \& SpUnARova, 2005).

\section{Collection storage, fumigation and restoration}

After the interior redecoration of Karlovac Gymnasium between 2005 and 2010 the room which housed the natural history collection was turned into a classroom and several cabinets with exhibits were placed in a new classroom and several in a separate classroom for biology. The rest of the collection was placed in new cabinets between the two classrooms. During the enumeration of the collection some items were moved to the office for biology for safety reasons. Due to the bad condition of the collection it was decided to carry out disinfestation in order to continue the processing. Due to the institutional nature of the school, disinfestation and fumigation were carried out during the spring break when there were fewer people in the building. Grouping the collection into a smaller space resulted in a more cost-effective and environmental friendly process. Gases used for the process were phosphine $\left(\mathrm{PH}_{3}\right)$ and methyl bromine $\left(\mathrm{CH}_{3} \mathrm{Br}\right)$. After the completion, the spaces housing the collection were thoroughly ventilated and items were selected for restoration. The selection was based on the degree of damage of the items, the value of the item within the collection, its possible use for the upcoming exhibition and the available funds for the restoration. Therefore, a small number of exhibits (Tab. 1) were selected for thorough restoration while a larger number of items underwent only the most necessary interventions. Zoological and osteological items were restored by a senior taxidermist, and lithographs by a senior conservator (Fig. 4, Fig. 5). 
Tab. 1. Items selected for restoration

\begin{tabular}{|c|c|c|}
\hline Inv. No. & Type of the item & Name of the item \\
\hline 1105 & Lithograph (teaching aid) & $\begin{array}{l}\text { The content of the atlas: front and back views of the human skeleton } \\
\text { (Tab. I), human muscular system - front and back view (Tab. II), } \\
\text { organs of the human thoracic and abdominal cavity (Tab. III) and the } \\
\text { cardiovascular system of a human (Tab. IV). }\end{array}$ \\
\hline 877 & Lithograph (teaching aid) & $\begin{array}{l}\text { Drawings of the stages in the growth cycle of a flower from a flower } \\
\text { bud to a mature flower, flower diagrams, cross, longitudinal } \\
\text { cross-section of anthers, pollen formation and cross section of a fruit. }\end{array}$ \\
\hline 881 & Lithograph (teaching aid) & The morphology of simple leaves. \\
\hline 929 & Lithograph (teaching aid) & $\begin{array}{l}\text { The development cycle of true moss (Bryidae) and the morphology } \\
\text { of peat moss (genus Sphagnum). }\end{array}$ \\
\hline 935 & Lithograph (teaching aid) & $\begin{array}{l}\text { Floristic name tags of poisonous plants: common hedge hyssop } \\
\text { (Gratiola officinalis L.), deadly nightshade (Atropa bella-donna L.), black } \\
\text { henbane (Hyoscyamus niger L. ), bitter nightshade (Solanum dulcamara } \\
\text { L.), black nightshade (Solanum nigrum L.), ivy-leaved cyclamen } \\
\text { (Cyclamen europeum, valid name Cyclamen hederifolium Aiton), jimson } \\
\text { weed (Datura stramonium L.), poison darnel (Lolium temulentum L.), } \\
\text { mandrake (Mandragora officinalis, valid name Mandragora officinarum } \\
\text { L.) and common spindle (Euonymus europaeus L.) }\end{array}$ \\
\hline 963 & Lithograph (teaching aid) & $\begin{array}{l}\text { Dendrology of the poplar (Populus pyramidalis Roz., valid name } \\
\text { Populus nigra L.) }\end{array}$ \\
\hline 978 & Lithograph (teaching aid) & $\begin{array}{l}\text { Morphological and anatomical characteristics of bluntleaf cotton } \\
\text { (Gossypium herbaceum var. hirsutum (L.) Mast. 1874) }\end{array}$ \\
\hline 1078 & Lithograph (teaching aid) & The construction of a railway in the mountains. \\
\hline 1124 & Teaching aid & $\begin{array}{l}30 \text { different microscopic specimens of protozoa, sponges and body } \\
\text { parts of various invertebrates }\end{array}$ \\
\hline 191 & Lithograph (teaching aid) & $\begin{array}{l}\text { Skull of a lion (Felis leo accepted as Panthera leo), skull of a mole } \\
\text { (Talpa europaea), skull and incisors of a sheep (Ovis aries), skull of a } \\
\text { beaver (Castor fiber), skull of a South African anteater (Myrmecophaga } \\
\text { jubata), bones of the human hand (Homo sapiens), lower front leg } \\
\text { bones of a domestic dog (Canis lupus familiaris), lower front leg bones } \\
\text { of a South American tapir (Tapirus americanus), lower front leg bones } \\
\text { of a cow (Bos taurus), lower front leg bones of a horse (Equus caballus, } \\
\text { Equus ferus accepted as caballus), and fin bones of a common dolphin } \\
\text { (Delphinus Delphi, accepted name Delphinus delphis) }\end{array}$ \\
\hline 194 & Lithograph (teaching aid) & $\begin{array}{l}\text { Morphology of a stone marten (Mustela foina, accepted as Martes } \\
\text { foina), a European (common) otter (Lutra vulgaris, accepted as Lutra } \\
\text { lutra) and a European badger (Meles taxus, accepted as Meles meles) }\end{array}$ \\
\hline 246 & Lithograph (teaching aid) & $\begin{array}{l}\text { Drawings of the morphology and anatomy of the body of monoge- } \\
\text { nea, valid taxonomic name: family: Platyhelminthes (flatworms), } \\
\text { class: Monogenea (monogenea) }\end{array}$ \\
\hline 693 & $\begin{array}{l}\text { Zoological preparations/ } \\
\text { natural history objects }\end{array}$ & $\begin{array}{l}\text { Mounted specimen of the platypus (Ornithorhynchus paradoxus, } \\
\text { accepted as Ornithorhynchus anatinus (Shaw, 1799)) }\end{array}$ \\
\hline 721 & $\begin{array}{l}\text { Zoological preparations/ } \\
\text { natural history objects }\end{array}$ & $\begin{array}{l}\text { Mounted specimen of the European hedgehog (Erinaceus europaeus } \\
\text { Linnaeus, 1758), probably valid name Erinaceus roumanicus } \\
\text { Barrett-Hamilton, } 1900\end{array}$ \\
\hline 690 & $\begin{array}{l}\text { Zoological preparations/ } \\
\text { natural history objects }\end{array}$ & $\begin{array}{l}\text { Mounted specimen of the raven (Corvus pica, valid name Corvus corax } \\
\text { Linnaeus, 1758) }\end{array}$ \\
\hline 687 & $\begin{array}{l}\text { Zoological preparations/ } \\
\text { natural history objects }\end{array}$ & $\begin{array}{l}\text { Mounted specimen of hawfinch (Coccothraustes coccothraustes } \\
\text { (Linnaeus, 1758)) }\end{array}$ \\
\hline 704 & $\begin{array}{l}\text { Osteological preparations/ } \\
\text { natural history objects }\end{array}$ & $\begin{array}{l}\text { Hoof anatomy and bones of the lower leg of a horse (Equus ferus } \\
\text { caballus Linnaeus, 1758) }\end{array}$ \\
\hline 705 & $\begin{array}{l}\text { Osteological preparations/ } \\
\text { natural history objects }\end{array}$ & ot of an ox (Bos taurus Linnaeus, 1758 \\
\hline
\end{tabular}



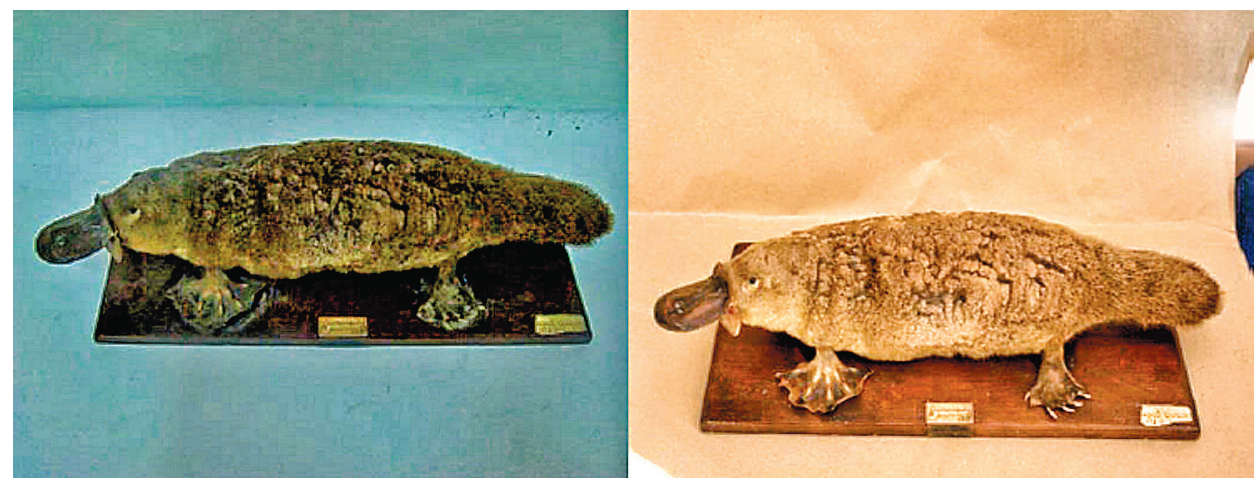

Fig. 4. Platypus before and after restoration (Inv. No. 693) (photo: L. Čorak)

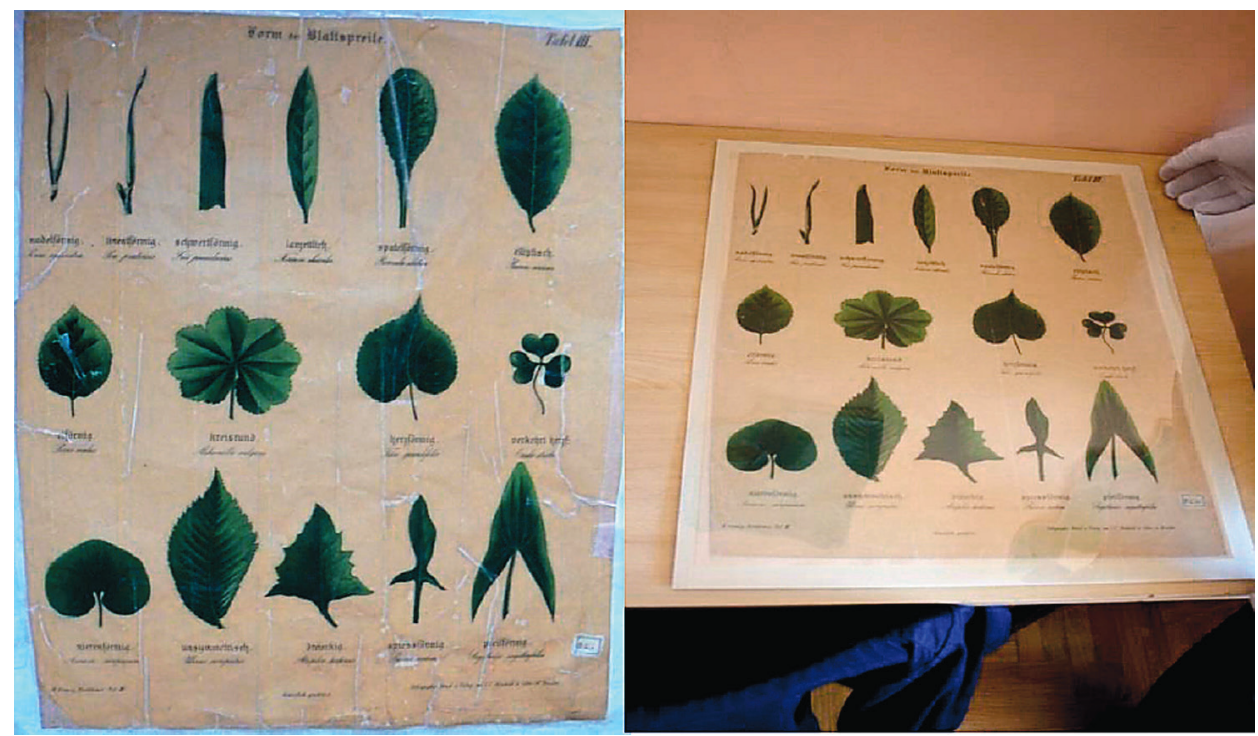

Fig. 5. Drawings of the morphology of simple leaves before and after restoration (Inv. No. 881) (photo: L. Črak)

\section{Photographing and basic protection measures}

Simultaneously with the process of restoration a basic, working version catalogue of the collection with amateur photographs was made. After the restoration, 122 potential exhibit candidates for the upcoming exhibition were photographed by a professional photographer.

After the examination, processing, disinfestation, restoration and photographing of the collection, it became evident that the conditions in which it was housed were not appropriate and could lead to further decay. This was aided by the fact that some of the items had been in use until recently. Therefore, some measures were taken to prevent further deterioration of the collection. They included: relocation of the sensitive items of the collection into the biology office, restricting the access to the collection, limiting the 
number of people in contact with it, handling the objects in accordance with the rules of museology (MARoEvić, 1993).

\section{Evaluation and categorization of the collection}

In order to categorize the items in the collection a model developed in the Natural History Museum of Rijeka was used (Arко-Pijevac, 2008). The properties of the collection for the categorization were: scientific (technical characteristics, methodology, covered areas, a larger number of specimens of species), expert (valid name of the species, date of the finding, habitat, site), educational (no expert properties, irrespective of the person / or institution) and historical (no expert properties, related to the person and / or institution). Since there was some incompatibility between the model and the characteristics of some items it was decided to categorize only the objects for which the model was developed (biological material - natural history objects).

\section{RESULTS}

\section{Condition of the collection}

After the entire collection had been processed and inventoried the following results were obtained: the total number of items was 1,153, out of which 518 were preserved, 448 were damaged, and 187 were significantly damaged which meant that less than a half of the collection ( $45 \%$ ) was in a satisfactory condition and needed no radical repairs. The rest of the collection was in a damaged condition (39\%) while the smallest part was badly damaged (16\%) (Fig. 6).

The status of the items was determined for each sub-collection (Tab. 2). The geological and mineral sub-collection had the best ratio between preserved and damaged items, except for the furniture (equipment), while the geographical and economic sub-collection had the most unfavourable ratio. The largest sub-collections, botanical and zoological, had negative ratios since the proportion of damaged items greatly exceeded $50 \%$, and the reasons for this were their frequent use in the classroom and the general lack of care because of lack of funding.

\section{Categorization of the collection}

Due to the need, as well as the motivation, to increase the cultural value of the collection, a categorization was made according to the model which was implemented in the Natural History Museum of Rijeka (ARKo-PIJEvaC, 2008). The model itself shows the real value of the collection. The categorization was done in order to determine the real value of the collection by taking into consideration the quality of information the collection contains. The following categories were used: scientific with the highest level of information and methodology of the profession, then expert, educational and historic. It is important to add that the scientific and expert categories have scientific data attached to the items and that those items are more important to science, whereas the educational and historic categories have no such data and are less scientifically important. Since the criteria for categorization of collections only apply to biological specimens - natural history objects, it was decided to categorize only those items. However, an attempt was nevertheless made to categorize the entire collection, but soon there was a great difficulty because of the inflexibility of the system and the idea 
Tab. 2. State of the items in the subcollections

\begin{tabular}{|l|c|c|c|c|}
\hline Subcollection & Preserved & Damaged & Badly damaged & Total \\
\hline Algological & 54 & 14 & 13 & 81 \\
\hline Anthropological & 14 & 14 & 5 & 33 \\
\hline Botanical & 56 & 116 & 25 & 197 \\
\hline Geographical and economic & 2 & 14 & 5 & 21 \\
\hline Geological and mineralogical & 22 & 0 & 4 & 26 \\
\hline Malacological & 125 & 53 & 6 & 184 \\
\hline Mycological & 30 & 12 & 0 & 17 \\
\hline Microbiological & 9 & 7 & 1 & 544 \\
\hline Zoological & 198 & 218 & 128 & 8 \\
\hline Furniture and other inventory & 8 & 0 & 0 & \\
\hline
\end{tabular}

\section{Condition of the items}

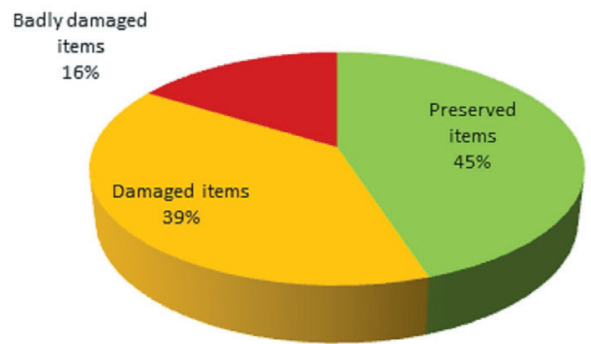

Fig. 6. Condition of the items in the collection

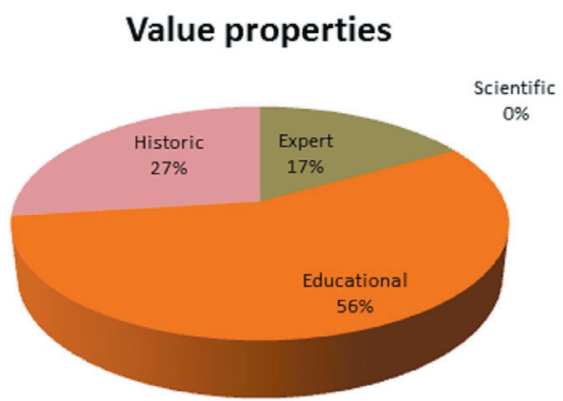

Fig. 7. Categorisation according to value

was dropped. The total number of natural history objects is 597, out of which 100 have expert properties, 336 educational and 161 historic while the highest level was not found (Fig. 7).

If one looks at the cultural component of value during categorization and the quality of specimens, it should be noted that the collection was made by the most eminent experts, taxidermists and private printing houses of the time. Out of the total number, 540 items (47\%) were made by unknown authors, while $614(53 \%)$ have an author and the place of production. If you look exclusively at natural history objects (biology specimens), for 244 it is possible to determine the taxidermist while for 353 it is not possible.

\section{DISCUSSION AND CONCLUSION}

\section{Neglected collection and the reasons for such a state}

Although it was rich, the collection of Karlovac Gymnasium was in a bad condition for several reasons. The most important one was the fact that its primary goal was to be used in the classroom. Biology was taught in a completely different way at the turn of the $20^{\text {th }}$ century and the collection was used significantly more. A large number of items in the collection ensured realism in teaching so they were exposed to damage and decay. Such a method prevailed until the end of World War II. In the second half of the $20^{\text {th }}$ century new teaching aids began to emerge and the items in the natural 
history collection were used less and less. There were problems with the maintenance of the collection and replacement of the worn-out teaching aids. Replacing the formalin in the jars, cleaning, disinfestation, labeling with modern taxonomic designations were the tasks performed by employees who were in charge of the natural history classroom. Initially, these tasks were probably performed regularly, but later they were stopped or done rarely so that they had no positive effect. Due to either the lack of funding, changes in the curriculum, negligence of the teaching staff or other reasons, the collection kept deteriorating and it was used less and less in the classroom. At the turn of the $21^{\text {st }}$ century the attitude towards the collection changed and it became questionable whether it could survive and be saved. Because of the hard work and dedication of a small number of the employees and help provided by the Karlovac City Museum, it was preserved and it was given the status of cultural heritage. The remaining question is how many items from the original collection are still in existence. It is more difficult to answer this question because the procurement records are incomplete. If we compare the inventory records containing offers from the taxidermists of the time (REILING \& Spunarova, 2005) with the curriculum and the occasional enlargement of the collection we can claim that at the time when it was used the most it had more than 4000 items. Since the collection originally had more than 4000 items, today's number of 1153 is extremely favorable given the fact that it suffered from various adverse circumstances in its history (Reiling \& Spunarova, 2005; Anonymous, 1874/75). This number also shows the exceptional quality of the items that were able to withstand a century and a half of lack of maintenance and being used in the classroom.

\section{Restoration of the collection and future plans}

After the processing of the collection and the initial restoration work the following question can be raised: how and what next? The collection is not used in teaching, the items are not taken out of the cabinets and the microclimatic conditions in which they are housed are more stable, disinfestation has been conducted and a part of it was restored (Fig. 8). But, those were only initial steps which have unfortunately just slowed the deterioration of the collection and were able to stop it only in some specific cases. More than $50 \%$ of the collection is in need of some kind of conservation and restoration. The whole collection is inadequately housed, which poses a serious threat to its existence. This calls for immediate response, the goal of which should be completely to stop the further deterioration of the collection. The first step is to find a suitable place to house the collection with favorable conditions. Since it is mixed, and the items are made of various materials, the relative humidity $(\mathrm{RH})$ should be around $50 \%$, and the temperature should be constant around $20^{\circ} \mathrm{C}$ (Maroević, 1993; Vinterhalter, 1993; COOPER, 2015; ČORAK, 2015). By putting the collection in such a place and by introducing planned and continual disinfestation it would be possible to almost completely stop the deterioration of the collection and it would be possible to begin the restoration of the items. Solving this problem also raises a professional and ethical dilemma. At the moment the only suitable place that could house such a collection is the Karlovac City Museum where the items would be well looked after. But the collection is the property of the school and it has an important role in presenting the school to visitors. Moreover, it was its essential part through history and today and it would be a pity if the collection were not in the school. However, the Museum's duty is to protect all the cultural heritage in the city of Karlovac and it must not ignore the current situation regarding the collection (Official Gazette 2015; ICOM, 2013). Therefore, it was decided to move 
the sensitive or damaged items in the collection, as well as rare and important objects, to the Museum as a temporary loan where they will be restored. The rest of the collection, which can survive in the current conditions, will remain in the school where it is planned to find an adequate place for the collection. In time this place will be adapted so that it can provide the best possible conditions for the collection and be used as a semi-open and/or closed storage area, allowing further professional and scientific work on the collection as well as welcoming groups of visitors. The ideas for such a space include devices which maintain constant temperature conditions (air-conditioning), humidity (dehumidifiers and humidifiers) and light (shutters on the windows and glass with UV protection) (VINTERHALTER, 1993). In addition, the collection needs

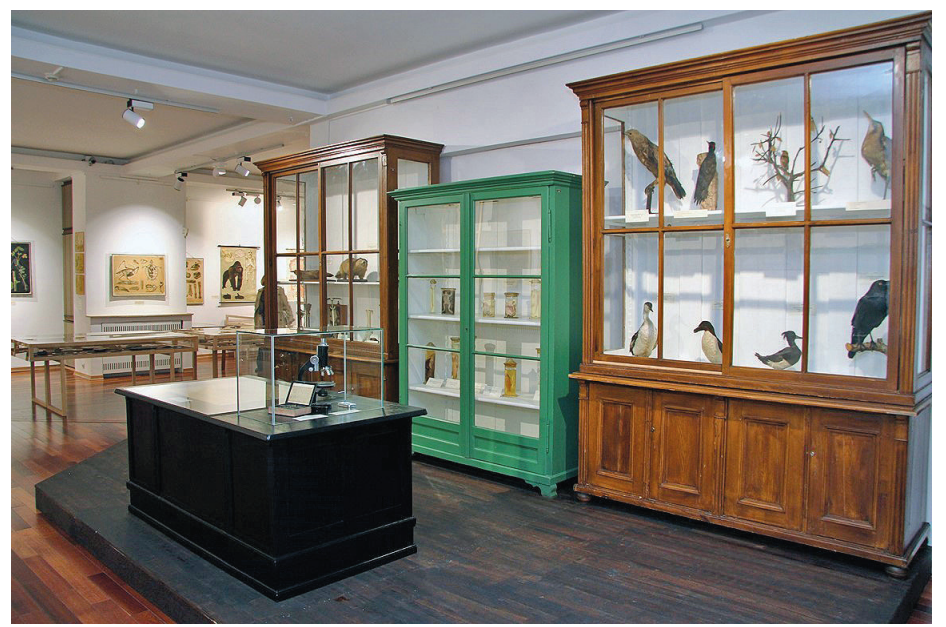

Fig. 8. Restored cabinets and part of the collection before the exhibition (photo: O. Budimir)

to be insured and a person to look after it needs to be appointed. To handle such a complex collection it is of the utmost importance to establish cooperation with the Karlovac City Museum, which has a trained staff able to maintain the collection.

\section{Categorization and cultural value}

The categorization of the collection has been made in order to estimate its real cultural value. Although the plan was to categorize the entire collection, it was made just for the items of characteristic biological material (natural history objects). The reason for this partial categorization was the incompatibility of the model which was used in categorization (Arko-Pijevac, 2008) with some of the items in the collection. Since the model was made for natural history collections, it refers exclusively to the collections where the items are arranged according to scientific fields and share the same groups of common characteristics according to which the categorization is done, and which arise from the methodology of the scientific discipline that deals with them. A part of the collection owned by Karlovac Gymnasium does not belong, according to its origin, to natural sciences (biology, chemistry, geology, physics, palaeontology, geography) but it also consists of various teaching aids (mostly lithographs and models), instruments (for example microscopes) and books. In terms of their characteristics, such items significantly differ from natural history objects and it is not possible to apply the 
existing model of categorization to them. At first there were strong attempts at developing a better model, but that proved exceedingly difficult without outside help and additional funding and since the collection research and preparations for exhibition were prioritised, it was decided to categorize only the natural history objects and to develop a new model of categorization at a later stage, as a part of a separate project that will insure the ability to categorize mixed collections like that in Karlovac Gymnasium in the future. It is difficult to determine and explain the cultural value of the collection without a generally accepted and flexible model. According to the model of the Natural History Museum in Rijeka, most of the collection has educational and historical importance which can easily be seen if you look at its function. But this only applies to one part of the collection (natural history objects) and it is very questionable and unprofessional to speculate on the cultural value of the entire collection. Although has been listed as our cultural heritage, which has given it sufficient cultural value and much needed protection, this does not define its value or in which fields (scientific, professional, educational and historical) it is most important. Apart from that, the collection is in a relatively poor condition, which further decreases its value. Until a functional model of categorization is developed, its value will exclusively be subjective and inaccessible to the general public. And yet we can certainly claim that the collection has great potential and a high value for the cultural heritage of natural sciences in Karlovac because of its historical and educational aspects; nevertheless, a certain amount of effort and love must be invested in its restoration.

\section{ACKNOWLEDGEMENTS}

Authors would like to thank the following people for their help in writing this paper: Vlatka Mičetić-Stanković, for her great help and expert advice; Hrvojka Božić, for pro-ofreading the Croatian text; Denis Plavetić, for the English translation; Henri Reiling, for his expertise and literature; Petar Crnčan, for the determination of a part of the Malacological Collection.

Received March 29, 2017

\section{REFERENCES}

Anonymous, 1874/75: Jahresbericht der k.k. Ober-Realschule zu Rakovac in der k. k. Kroatisch-Slavonische-Militär Grenze am Ende des Schuljahres (Report of The Imperial and Royal Realschule).

Anonymous, 2016: Republic of Croatia - Register of cultural assets (Z-6469 - Prirodoslovna zbirka Gimnazije Karlovac): http://www.min-kulture.hr/default.aspx?id=6212\&kdId=207574158 (Accessed: January 5 2016).

Arko-Pijevac, M., 2008: Kategorizacija zbirki Prirodoslovnog muzeja Rijeka. I kongres muzealaca Hrvatske, Zagreb, 12 - 14. 11. 2008., oral presentation (lecture).

Cooper, J., 2015: Temperature and Relative Humidity (RH) General information on temperature and collections: http://www.amnh.org/our-research/natural-science-collections-conservation/general-conservation/preventive-conservation/temperature-and-relative-humidity-rh (Accessed: November 16 2015).

ČorAK, L., 2015: Entomološka zbirka u nastajanju: stručna metodologija, muzejska obrada te važnosti i potencijali zbirke u fundusu Gradskog muzeja Karlovac s posebnim naglaskom na kornjaše (Coleoptera), Stručni rad za polaganje ispita za stručno zvanje kustosa. Muzejski dokumentacijski centar (MDC), Zagreb, 37 pp.

FARR, D.F. \& Rossman, A.Y., 2015: Fungal Databases, U.S. National Fungus Collections, ARS, USDA. Retrieved April - August 2015, from https://nt.ars-grin.gov/fungaldatabases/. 
Froese, R. \& Pauly D. (Eds.), 2015: FishBase. World Wide Web electronic publication. www.fishbase.org, version (1020/15). (Accessed: April - August 2015).

Guiry, M.D. \& Guiry, G.M., 2015: AlgaeBase. World-wide electronic publication, National University of Ireland, Galway. http://www.algaebase.org; searched on April - August 2015.

Hayward, B.W., Le Coze, F. \& Gross, O., 2015: World Foraminifera Database. Accessed at http://www. marinespecies.org/foraminifera on April - August 2015.

ICOM: ICOM code of ethics for natural history museums, 2013: http://www.icom-croatia.hr/wp-content/ uploads/2014/01/nathcode_ethics_en.pdf (Accessed: November 8 2015).

International Code of Zoological Nomenclature, 2015: http://iczn.org/code (Accessed: November 5 2015).

LePAGE, D., 2015: AVIBASE - the world bird database: http://avibase.bsc-eoc.org/avibase.jsp?lang=EN (Accessed: April - August 2015).

Maroević, I., 1993: Uvod u muzeologiju. Zavod za informacijske studije Odsjeka za informacijske znanosti, FFGZ, Zagreb, 286 pp.

Milınković, A., 2011: Botanika u srednjim školama grada Karlovca od druge polovice XVIII. st. do početka XX. st. Printera grupa d.o.o., Sv. Nedelja, 449 pp.

Nikolić, T. (ed.), 2015: Flora Croatica Database, On-Line (http://hirc.botanic.hr/fcd). Department of Botany, Faculty of Science, University of Zagreb. (Accessed: April - August 2015).

Official GazetTe, 2015: Law on Museums. http://narodne-novine.nn.hr/clanci/sluzbeni/2015_10_110_2121. html (Accessed: December 22 2015).

Official GazetTe, 2011: Ordinance on the form, content and manner of keeping the register of cultural assets of the Republic of Croatia. http://narodne-novine.nn.hr/clanci/sluzbeni/2011_07_89_1905.html (Accessed: January 5 2016).

Reiling, H. \& Spunarova, T., 2005: Vaclav Frič (1839-1916) and his influence on collecting natural history. Journal of the History of Collections, 17(1), 23-43.

Vinterhalter, J., 1993: Osnove zaštite i izlaganja muzejskih zbirki. Muzejski dokumentacijski centar (MDC), Zagreb, 147 pp.

Wilson, D. E. \& Reeder, D.A.M. (eds), 2005: Mammal Species of the World. A Taxonomic and Geographic Reference (3rd ed), Johns Hopkins University Press, Baltimore, 2,142 pp. (Available from Johns Hopkins University Press, http://www.press.jhu.edu). https://www.departments.bucknell.edu/bio$\log$ /resources/msw3/:(Accesed: May 2018).

WoRMS Editorial BoARD, 2018: World Register of Marine Species. Available from http://www.marinespecies.org at VLIZ. Accessed April - August 2015. doi:10.14284/170. 
